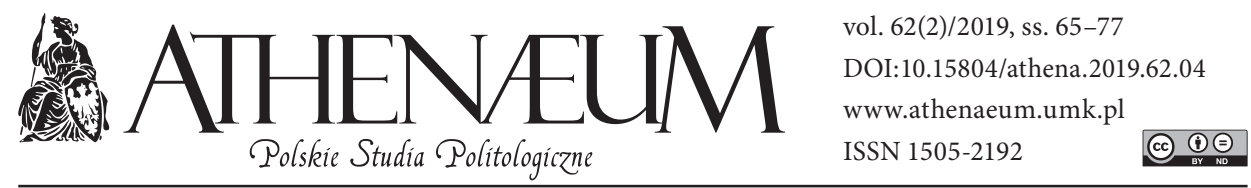

\title{
KONTRAKT SPOŁECZNY W KONCEPCII PAŃSTWA ROZWOJOWEGO NA PRZYKŁADZIE AZJI WSCHODNIEJ
}

\author{
THE SOCIAL CONTRACT IN THE CONCEPT \\ OF DEVELOPMENTAL STATE: THE CASE OF EAST ASIA
}

Andrzej Bolesta* ()

\begin{abstract}
ABSTRAKT
Koncepcję państwa rozwojowego uznaje się za kluczową $\mathrm{w}$ historycznym procesie modernizacji gospodarek wschodnioazjatyckich. Jednym z kluczowych jej elementów jest kontrakt społeczny, definiujący wzajemne powiązania uczestników procesów rozwojowych: elity politycznej, biurokracji gospodarczej, społeczeństwa oraz sektora biznesowego. Ich interakcja jest zdefiniowana poprzez pojęcie „osadzonej autonomii”. Społeczeństwo i biznes mogą wpływać na państwo poprzez instytucjonalnie umocowane kanały komunikacji; niemniej jednak państwo pozostaje $\mathrm{w}$ dużym stopniu autonomiczne $\mathrm{w}$ procesie podejmowania decyzji dotyczących polityki rozwojowej oraz budowy instytucji, co w rezultacie umożliwia pomnażanie zasobów. Państwo funkcjonuje poprzez koalicje, mające po pierwsze za zadanie osłabienie pozycji społeczeństwa, ale jednocześnie upodmiotowienie pewnych jego elementów; po drugie włączenie w procesy rozwojowe części sektora biznesowego poprzez stworzenie sojuszu państwa i biznesu.
\end{abstract}

The concept of the developmental state is considered to be the framework for the historical process of modernisation of the East Asian economies. One of its key elements is social contract, defining the relational aspects between the participants of the development process: the political elite, economic bureaucracy, society, the business sector. Their interaction is defined by the concept of "embedded autonomy". Society and the business sector can influence the state through institutional channels; nevertheless, the state remains largely autonomous in the decision-making process regarding development policy and institution building, which allows for an increase in wealth. The state operates through coalitions aimed at, firstly, weakening the society and, at the same time, empowering some of its components; secondly, incorporating business into the development process by creating a statebusiness alliance.

* Collegium Civitas w Warszawie, Centrum Gospodarek Azjatyckich. 
Słowa kluczowe: rozwój; Azja Wschodnia; kontrakt społeczny; uprzemysłowienie; państwo rozwojowe
Keywords: development; East Asia; social contract; industrialization; developmental state

\section{WSTĘP}

Koncepcja państwa rozwojowego jest teoretyczną podstawą do budowania specyficznych struktur politycznych i instytucjonalnych, których głównym zadaniem jest tworzenie warunków dla przyspieszenia rozwoju społeczno-gospodarczego w krajach słabo rozwiniętych, tak aby w relatywnie krótkim okresie mogły one nadrobić zaległości rozwojowe wobec wysoko rozwiniętych państw zachodnich. Dynamizacja procesów rozwojowych następuje poprzez uprzemysłowienie.

Jedną z dominujących cech koncepcji jest specyficzny kontrakt społeczny, który określa zasady interakcji i role poszczególnych uczestników procesu uprzemysławiania, mianowicie państwa wraz z jego biurokracją odpowiedzialną za kwestie rozwojowe, społeczeństwem i jego różnymi warstwami oraz sektorem biznesowym. Poniższy artykuł analizuje relacje pomiędzy państwem a społeczeństwem $\mathrm{z}$ jednej strony a państwem i biznesem $\mathrm{z}$ drugiej w procesie uprzemysławiania. Część pierwsza jest opisem koncepcji państwa rozwojowego, w tym jego istotnych elementów, takich jak uprzemysłowienie i kontrakt społeczny. Część druga analizuje relacje pomiędzy państwem a społeczeństwem, natomiast część trzecia egzaminuje przymierze państwa $\mathrm{z}$ biznesem.

\section{PAŃSTWO ROZWOJOWE, UPRZEMYSŁOWIENIE I KONTRAKT SPOŁECZNY}

Koncepcja państwa rozwojowego sięga swoimi korzeniami drugiej połowy XIX w. i wydarzeń w Europie i Azji. Otto von Bismarck jako kanclerz Rzeszy wprowadził szereg regulacji prawnych dotyczących systemu ubezpieczeń społecznych i systemu emerytalnego, co stworzyło pierwsze podwaliny dla późniejszego państwa opiekuńczego w kapitalistycznej Europie Zachodniej. Wyznaczył w ten sposób nową rolę państwa wobec społeczeństwa jako gwaranta nie tylko politycznego porządku, ale i społecznej stabilności. W tym samym czasie poważne przemiany systemowe i instytucjonalne zachodziły w Japonii. W okresie Meiji (1868-1912) Japonia przeszła rewolucyjne zmiany od samoizolującego się 
państwa feudalnego, kierowanego przez regentów szogunów, do regionalnego imperium o kapitalistycznej gospodarce (Maddison, 2007). Zmiany roli i pozycji państwa oraz mechanizmów gospodarczych były inspirowane po części zmianami w Rzeszy Niemieckiej. Japoński premier Ito Hirobumi kilkakrotnie odbył misje badawcze do Europy i Stanów Zjednoczonych, aby studiować tamtejsze instytucje, prawodawstwo i działania władz wykonawczych. Ówczesne reformy w Japonii stworzyły podwaliny dla systemowych i instytucjonalnych regulacji, które później określono mianem państwa rozwojowego.

Sama koncepcja narodziła się wraz z publikacją Chalmers’a Johnsona (1982) pod tytułem MITI and the Japanese Miracle: The Growth of Industrial Policy, 1925-1975. W swojej pracy Johnson wykazał korelację pomiędzy rozwiązaniami instytucjonalnymi a sukcesem rozwojowym. Japonia, w dużej mierze rolniczy i raczej niezamożny kraj, staje się bogatą, wysoko rozwiniętą gospodarką w dużo krótszym okresie, niż miało to miejsce w państwach Europy Zachodniej i Ameryki Północnej. Analiza Johnsona dotycząca Japonii została następnie wsparta studiami nad Koreą Południową Alice Amsden (1989) i Bruca Cumingsa (1984) i nad Tajwanem Roberta Wade’a (1990). Sukcesy państw rozwojowych Azji Wschodniej to fenomen drugiej połowy XX w. To okres od lat 50. do 80. uznawany jest za ten, w którym kandydaci tzw. konsensusu czy też azjatyckiej trójki - Japonia, Korea Południowa i Tajwan - dokonały największego skoku cywilizacyjnego. Okres szybkiego wzrostu Japonii przypada na dekady lat 50., 60. i 70., natomiast Korei Południowej i Tajwanu - na lata 60., 70. i 80.

W literaturze przedmiotu państwo rozwojowe jest często utożsamiane z procesem uprzemysławiania, kierowanym przez państwo (ang. state-led industrialisation). Przykładowo Evans (1995) twierdzi, iż koncepcja leży u strukturalnych podstaw angażowania państwa w proces transformacji przemysłowej i że władze państw rozwojowych nie tylko kierowały tymże procesem, ale przede wszystkim były jego głównym sprawcą. Woo-Cumings (1999) traktuje koncepcję państwa rozwojowego jako wytłumaczenie dla dynamicznego uprzemysławiania Azji Wschodniej. Johnson (1982) w określanej za przełomową analizie sukcesów gospodarczych Japonii - głównego przedstawiciela koncepcji państwa rozwojowego - skoncentrował się właśnie na procesie uprzemysławiania.

Wśród państw rozwojowych proces uprzemysławiania rozpoczął się od polityki substytucji importu (ang. import substitution industrialisation - ISI), zgodnie z którą zwiększano rodzimą produkcję, aby zastąpić na rynku dobra importowane towarami wytwarzanymi lokalnie. Zgodnie z opinią Haggarda (1990) „ISI może pojawić się w sposób naturalny, jako wynik problemów w bilansie płatniczym, 
efekt przerw w dostawach/podaży, związanych np. z wojną, albo ze względu na rozwój rynku wewnętrznego. ISI rozwija się dzięki próbom niwelowania problemów związanych z bilansem płatniczym, w szczególności poprzez kontrolę handlu i wymiany walut, oraz przez politykę przemysłową zaprojektowaną tak, aby podnieść stopę zwrotu z [rodzimej] produkcji przemysłowej” (Haggard, 1990, s. 26). Haggard (1990) rozróżnia trzy fazy ISI; w pierwszej dochody państwa pochodzą z eksportu dóbr niskoprzetworzonych. Z zagranicznych kredytów finansowany jest zakup komponentów i maszyn. Import służy zatem rozwojowi lokalnego wytwórstwa. W fazie drugiej utrzymuje się uzależnienie od eksportu surowców i żywności oraz od kredytów zagranicznych, gdyż inwestycje poczynione w moce wytwórcze powodują wzrost zapotrzebowania na komponenty. Faza trzecia charakteryzuje się tym, iż polityka substytucji importu zostaje uzupełniona przez wzrost produkcji przemysłowej ukierunkowanej na eksport. Zatem ISI stopniowo przechodzi w industrializację zorientowaną na produkcję eksportową (ang. export-orientated industrilisation - EOI). EOI jest uważana za kluczową w polityce rozwojowej, z uwagi na to, iż wysoka dynamika wzrostu gospodarek państw rozwojowych była możliwa w dużej mierze dzięki zwiększaniu eksportu, a eksport był możliwy dzięki zakrojonym na szeroką skalę działaniom wspierającym, zarówno produkcję eksportową, jak i sam proces sprzedaży za granicą. Ponadto EOI powodowała powstanie strukturalnej zależności państwa wdrażającego jej zapisy ze światową gospodarką, gdyż ta ostatnia stawała się rynkiem zbytu dla produkcji krajowej. Poziom produkcji celowo przekraczał bowiem możliwości absorpcyjne rynku wewnętrznego. EOI tym różni się od ISI, że nacisk jest położony na wspieranie eksportu, a zatem także selektywną liberalizację handlu, w większym zakresie niż ma to miejsce przy ISI. Towarzyszą jej liczne działania w sferze polityki handlowej oraz finansowej, takie jak tworzenie barier taryfowych i pozataryfowych, manipulowanie kursem walutowym czy stopami procentowymi. Są one dużo bardziej zawansowane instytucjonalnie niż w przypadki ISI. Część badaczy widzi główną różnicę w procesie uprzemysławiania Azji Wschodniej i Ameryki Łacińskiej w tym, że pierwszy region po okresie ISI wdrażał EOI, podczas gdy drugi pozostał przy ISI (Kong, 2000). Kolejnym ważnym elementem typowej polityki rozwojowej państw rozwojowych jest stopniowe podwyższanie zawansowania technologicznego produkcji krajowej.

Proces szeroko zakrojonej restrukturyzacji gospodarki, czym jest de facto jej dynamiczne uprzemysławianie, nie byłby możliwy bez zaangażowania wszystkich aktorów życia gospodarczego państwa, a zatem państwa i państwowej biurokracji, 
sektora biznesowego oraz społeczeństwa. Państwa rozwojowe, aby efektywnie restrukturyzować narodową gospodarkę, musiały zawrzeć swoisty kontrakt społeczny, który z jednej strony definiował relacje pomiędzy uczestnikami procesu, a z drugiej wyznaczał ich role. To specyficzny kontrakt społeczny legł u podstaw efektywnej machiny państwowo-społecznej, umożliwiającej zdynamizowanie rozwoju.

Hobbesa uważa się za pierwszego nowożytnego filozofa, który sformułował szczegółową teorię kontraktu. Teoria ta traktuje o zrzekaniu się jednostek praw na rzecz suwerena (lewiatana) w zamian za bezpieczeństwo i ochronę. Sto lat później Rousseau oparł swoją teorię umowy społecznej na koncepcji powszechnej suwerenności, która mimo iż zawierała odniesienia do indywidualistycznych praw jednostek, podkreślała także wagę „woli ogółu” czy też kolektywu. Prawa jednostki kolejne sto lat później uwypuklił Proudhon. Choć w powyższym artykule nie ma miejsca na szczegółową analizę historii umowy społecznej, warto podkreślić, iż kontakt społeczny w przypadku państw rozwojowych czerpie częściowo z teorii Hobbesa i Rousseau i odwołuje się do kwestii oddania państwu części suwerenności jednostki, przy jednoczesnym respektowaniu kolektywnej woli społeczeństwa jako uczestnika procesu rozwoju.

Analiza relacji pomiędzy uczestnikami procesu rozwojowego w ramach koncepcji państwa rozwojowego jest o tyle ważna, iż sieć powiązań polityczno-biurokratyczno-finansowych, kształtujących życie gospodarcze w kapitalistycznej Azji Wschodniej (Woo-Cumings, 1999), stanowi organizacyjne jądro funkcjonowania państwa. Aby zrozumieć te zależności i ich rolę, należy przeegzaminować relacje łączące cztery główne grupy aktorów państwa rozwojowego: elitę polityczną, aparat biurokratyczny, ze szczególnym uwzględnieniem części administracji odpowiedzialnej za gospodarkę, rozwój i modernizację, społeczeństwo oraz sektor biznesowy.

\section{PAŃSTWO A SPOŁECZEŃSTWO}

W swoich badaniach nad państwami w procesie transformacji przemysłowej Evans (1995) wyróżnił dwa typy idealne, charakteryzujące relacje pomiędzy społeczeństwem a państwem: mianowicie państwa rozwojowe oraz państwa, które można określić wspólnym mianem jako grabieżcze, rozbójnicze bądź łupieżcze (ang. predatory). Elity polityczne krajów grabieżczych eksploatują i uciskają społeczeństwo, podkopując tym samym fundamenty rozwoju społeczno-gospo- 
darczego, nawet te, rozumiane w wąskim znaczeniu, jak akumulacja kapitału. Pareto (1966) podkreśla, iż główny proces tam zachodzący to przejmowanie zasobów społeczeństwa przez elity rządzące za pomocą środków legalnych i nielegalnych. Nozick (1974) uważa, iż zdolności państwa grabieżczego zależą od poziomu kontroli, jaki elity polityczne posiadają nad zasobami siłowymi, ekonomicznymi i politycznymi. Zair (obecnie Demokratyczna Republika Konga) za czasów Mobutu Sese Seko niegdyś, a ostatnio Zimbabwe rządzone przez Roberta Mugabe (do listopada 2017 roku), to sztandarowe przykłady państw grabieżczych. Według Evansa (1995) zasadnicza różnica między państwem rozwojowym a krajem grabieżczym polega na tym, iż te drugie nie posiada zdolności powstrzymywania tych, którzy czerpią zyski kosztem społeczeństwa. Koterie są jedynym gwarantem spójności. Maksymalizacja osobistych korzyści bierze górę nad dobrem wspólnym. Związki społeczeństwa z państwem to związki z konkretnymi jednostkami, a nie pomiędzy grupami społecznymi a hierarchą państwową. W związku z powyższym współzależności w krajach grabieżczych i rozwojowych przybierają dwie przeciwstawne formy, a zatem przynoszą bardzo różne efekty. W przypadku państwa grabieżczego następuje bogacenie się elit kosztem malejących zasobów społeczeństwa, podczas gdy w przypadku państwa rozwojowego te zasoby są pomnażane przy kohabitacji elit politycznych i społeczeństwa i obie grupy z tego korzystają. Ten związek, w przypadku państwa rozwojowego, określany jest mianem „osadzonej autonomii” (ang. embedded authonomy). Według Evansa (1995), ta autonomia państwa, a zatem także administracji państwowej, umożliwia bezstronne wykonywanie obowiązków związanych ze sterowaniem organizmem państwowym, gdyż elity i biurokracja posiadają pewną niezależność, a zatem także odporność na naciski i żądania różnych grup interesu, oraz posiadają zdolność efektywnego reagowania i przeciwdziałania tymże naciskom. Jednocześnie to osadzenie ma miejsce w ramach konkretnych współzależności społecznych, które wiążą państwo ze społeczeństwem i tworzą instytucjonalne kanały komunikacji, umożliwiające ciągłe negocjacje i renegocjacje celów rozwojowych i polityki rozwojowej. Osadzona autonomia zapewnia z jednej strony autonomię do działania, która umożliwia opracowanie i wdrażanie możliwie najbardziej efektywnej strategii rozwoju państwa, z drugiej podtrzymuje dialog społeczny pomiędzy władzą a społeczeństwem, niezbędny dla legitymizacji działań władzy i uwzględnienia jak najszerszej grupy postulatów społecznych. Według Waldnera (1999) tenże dialog jest potrzebny w celu tworzenia koalicji państwa z różnymi grupami nacisku, włączając w to prywatny sektor biznesowy, tak aby minimalizować opozycję wobec konstruktywnych strategii rozwojowych. 
Istnieją sprzeczne opinie co do charakteru niezbędnych koalicji i ich zasadności. Waldner (1999) uważa, iż powinny one być wąskie i ograniczone, a zatem konserwatywne, podając przy tym przykład Tajwanu i Korei Południowej. Takie konserwatywne koalicje pomiędzy państwem a dużym biznesem wykluczają z nich dużą część społeczeństwa i pozostałą część biznesu, i w ten sposób minimalizują potrzebę tak zwanych „płatności postronnych” (ang. side payments), czyli koncesji wobec niektórych grup społecznych w celu zyskania ich poparcia dla ogólnej trajektorii rozwojowej. Natomiast Doner Ritchie i Slater (2005) twierdzą, że to szerokie koalicje przyczyniły się do stworzenia palety instytucji rozwojowych oraz wzmocniły instytucje państwowe. Dla Donera i in. (2005) płatności postronne nie stanowiły problemu $\mathrm{z}$ uwagi na fakt, iż w warunkach ograniczonych środków finansowych oraz ciągłego zagrożenia zewnętrznego (cech charakterystycznych historycznych państw rozwojowych) po prostu nie mogły mieć miejsca.

Leftwich (2000) oferuje trochę inną niż Evans (1995) narrację dotyczącą relacji pomiędzy państwem a społeczeństwem, wyszczególniając kilka elementów definiujących; mianowicie, zdeterminowaną elitę polityczną ukierunkowaną swoimi działaniami na rozwój, polityczną autonomię państwa, silną i autonomiczną biurokrację gospodarczą, słabe i podporządkowane społeczeństwo, zdolność państwa do wpływania nawet na prywatne interesy gospodarcze, mieszankę represji i nierespektowania praw człowieka, legitymizację działań władzy opartą na wynikach rozwojowych. Leftwich (2000) sugeruje występowanie pewnej nierównowagi. Po jednej stronie mamy silne państwo zdolne do narzucania prywatnym podmiotom gospodarczym, grupom społecznym i jednostkom swoich preferencji gospodarczych, po drugiej słabe społeczeństwo bez zdolności narzucania swojej woli władzy. Wielu badaczy zgadza się z opinią Leftwicha (2000) w kontekście relacji w państwie rozwojowym. Stubbs (2009) uważa za istotny fakt, że słabe społeczeństwo nie jest w stanie przeciwstawić się silnemu państwu. Amsden (1989) pokazuje to na przykładzie Korei Południowej. Siła i konsolidacja państwa w Korei Południowej była możliwa dzięki słabości klas społecznych; robotnicy stanowili małą część społeczeństwa, kapitaliści byli uzależnieni od państwa (np. kontraktami i przywilejami), arystokracja została rozbita dzięki reformie rolnej, a na terenach wiejskich dominowały małe gospodarstwa rolne, zatem chłopstwo nie mogło mieć realnego wpływu na politykę.

W przypadku państw rozwojowych podporządkowanie sobie mieszkańców terenów wiejskich odbywało się poprzez reformę rolną, polegającą na redystry- 
bucji ziemi, a w konsekwencji zmianie relacji własności ziemi (Cumings, 1984, Haggard, 1990). W zasadzie we wszystkich państwach rozwojowych cele reformy były dwa: po pierwsze, poprzez redystrybucję ziemi, osłabienie pozycji posiadaczy ziemskich i obszarników - z reguły konserwatywnej grupy nastawionej antymodernizacyjnie, dysponującej znacznymi zasobami finansowymi oraz wpływami i potencjalnie zdolnej do przeciwstawienia się polityce rozwojowej państwa, która miała za zadanie szeroko zakrojoną transformację gospodarki; po drugie, uzyskanie poparcia dla swoich działań wśród uboższych mieszkańców wsi - małorolnego chłopstwa i biedoty poprzez przekazanie im gruntów rolnych pod uprawy. Polityczne osłabienie obszarników oraz emancypacja biedoty skutecznie eliminowała opozycję wobec polityki rozwojowej państwa. Reforma miała także dodatkowy skutek: zwiększała produkcję rolno-spożywczą, co miało strategiczne znaczenie dla państwa. Grunty, leżące dotychczas odłogiem, a będące przed reformą własnością arystokracji i posiadaczy ziemskich, nowi właściciele zaczęli uprawiać, gdyż często było to dla nich jedyne możliwe źródło utrzymania.

W historycznych państwach rozwojowych klasę robotniczą zawsze charakteryzował brak przywilejów (Gallagher, 2005). Cumings (1984) podkreśla, iż ta grupa społeczna nie uczestniczyła w procesie decyzyjnym, dotyczącym kierunków rozwoju Korei Południowej i Tajwanu w latach 50. Haggard (1990) utrzymuje, iż wszystkie kraje z tzw. grupy nowo uprzemysłowionych (ang. newly industrilised countries - NIC) charakteryzowały się słabością klasy robotniczej z uwagi na brak mechanizmów reprezentacji umocowanych w prawie (przypadek Tajwanu) albo z uwagi na wszechobecne represje (przypadek Korei Południowej). Niemniej jednak, mimo że państwa Azji Wschodniej dbały o to, aby klasa robotnicza nie miała wpływu na codzienną politykę rozwojową i gospodarczą, dbały także o to, aby generować wśród robotników wsparcie dla swoich działań. Czyniły to poprzez konkretne interwencje w mechanizmy rynkowe, umacniające pozycję robotników i zwiększające zasobność finansową lokalnej klasy robotniczej. Przykładem może być tu polityka substytucji importu (ISI), która w naturalny sposób w krótkim okresie generowała dodatkowe zatrudnienie. Wnikliwy nadzór nad rynkiem pracy i monitoring klasy robotniczej miały swoje polityczne przyczyny wynikające z uwarunkowań geopolitycznych oraz przyczyny ekonomiczne. Bliskość państw komunistycznych (Chin, Korei Północnej, Związku Radzieckiego, Wietnamu Północnego) stwarzała większe prawdopodobieństwo wybuchu ideologicznie motywowanych niepokojów społecznych, które mogły przerodzić się w otwarty konflikt o zbrojnym charakterze. Natomiast efektem ekonomicznym odmawiania praw robotnikom była możliwość utrzymywania 
niskiego poziomu płac, a zatem początkowo utrzymywanie międzynarodowej konkurencyjności lokalnej produkcji.

Ważne jest, aby podkreślić tutaj jeszcze raz dwutorowy charakter relacji na linii władza - robotnicy oraz władza - chłopi. Waldner (1999) w swojej analizie Korei Południowej i Tajwanu pokazuje, iż robotnikom i chłopom odmawiano praw, ale jednocześnie pośrednio wspierano poprzez, przykładowo, reformę rolną czy politykę substytucji importu. Władze uważały, że trzeba te grupy społeczne zarówno wspierać, jak i kontrolować, aby uzyskać ich wsparcie dla polityki rozwojowej i wykorzystać w procesach modernizacyjnych.

\section{PAŃSTWO A SEKTOR BIZNESOWY}

Wielu ekspertów od gospodarek wschodnioazjatyckich więcej miejsca poświęca w swoich badaniach na relacje między władzą a biznesem, jako głównym elemencie definiującym model rozwojowy. Ta relacja jest często określana mianem przymierza czy też sojuszu państwa z biznesem (ang. state-business alliance) (Cumings, 1984; Wade, 1990; Robinson, White, 1998; White, 1988). Wade (1990) uważa, iż w przypadku Azji Wschodniej jest on oparty na czymś, co można określić mianem „szerokiego podążania” (ang. big followership). Opisuje to sytuację, w której rząd stwarza przedsiębiorcom warunki instytucjonalne i ekonomiczne korzystne dla prowadzenia biznesu w określonych sektorach gospodarki narodowej. Innymi słowy, rząd kreuje warunki dla rozwoju pewnego sektora i powoduje, iż jest on atrakcyjny dla nastawionych na maksymalizację zysków przedsiębiorstw. Czyni to częściowo poprzez eliminację ryzyka związanego z prowadzeniem działalności gospodarczej bądź bierze to ryzyko na siebie. Gdyby nie polityka rządu, tenże sektor nie byłby biznesowo atrakcyjny; przedsiębiorcy nie chcieliby ponosić ryzyka związanego z inwestowaniem. Sektor prywatny „podąża” zatem za rządem. Amsden (1989) podkreśla, iż rząd staje się podówczas także przedsiębiorcą, gdyż uzurpuje sobie prawo do przejmowania roli tradycyjnie zarezerwowanej dla biznesu poprzez podejmowanie decyzji: co, gdzie, w jakiej ilości i za jaką cenę będzie produkowane. Hall i Soskie (2001) określili tę sytuację mianem koordynowanej gospodarki rynkowej, w której firmy polegają w dużej mierze na mechanizmach pozarynkowych, koordynując swoje działania z innymi uczestnikami życia gospodarczego i politycznego. „Te gospodarki są rynkowe w sensie takim, iż inicjatywa spoczywa głównie w rękach firm, maksymalizacja zysków pozostaje ich głównym bodźcem działania, a te, które 
przynoszą straty, w większości bankrutują. [Niemniej jednak] państwo próbuje wpływać na rynek, określając, co jest zyskowne/rentowne, a co nie, [częściej] za pomocą manipulacji cenami (getting the prices wrong) niż [poprzez] bezpośrednią interwencję" (White, Wade, 1988, s 5-6). Doner i in. (2005) twierdzą, iż przymierze państwa $z$ biznesem nie ma mieć tutaj charakteru klientelistycznego, jak ma to często miejsce w krajach rozwijających się. Współpraca oparta jest na jasno określonych kryteriach w ramach każdego sektora, w transparentnym środowisku, zgodnie $\mathrm{z}$ literą prawa, przyjętymi zasadami i normami.

Z perspektywy ekonomicznej to przymierze zapewnia, że - cytując Donera i in. (2005) - „wykwalifikowane i kompetentne agencje rządowe, stanowiące część biurokracji ekonomicznej, kolaborują z zorganizowanymi przedstawicielami sektora prywatnego na rzecz zdynamizowania transformacji gospodarczej kraju od niskiego poziomu rozwoju do wysokiego" (Doner i in., 2005, s. 328). Przyśpieszenie jest możliwe dzięki wykorzystaniu atutów państwa i biznesu. Państwo zapewnia ogólną strategię i plan działania, który ma zmodernizować gospodarkę narodową, a zatem poprawić poziom życia w społeczeństwie, podczas gdy biznes wdraża tenże plan, racjonalizując go poprzez efektywne mechanizmy produkcji i zarządzania. Oczywiście trudno jest mówić o jednym spójnym modelu kohabitacji państwa i biznesu w Azji Wschodniej. Jak twierdzi Haggard (1990), zależy on od faktycznych możliwości biznesowych kreowanych przez instytucje polityczne i zdolności samego rodzimego sektora biznesowego.

Sojusz ten jest często postrzegany jako źródło korupcji, będącej przez to nieodzownym elementem instytucjonalnego ładu państwa rozwojowego. W przypadku Azji Wschodniej badacze są podzieleni, jeśli chodzi o pogląd dotyczący zakresu i wpływu korupcji na zdolności rozwojowe państw. Jedni uważają, iż jest manifestacją porażki instytucji politycznych i państwa (Guo, $\mathrm{Hu}$, 2004). Powoduje ona bowiem łamanie zasad prawnych i organizacyjnych w celu wykorzystania środków i dóbr publicznych dla celów prywatnych. Jest transakcją wymiany wpływów politycznych na osobiste zyski (Kwong, 1997). Niewątpliwie kraje Azji Wschodniej, jak i inne regiony świata, nigdy nie były odporne na korupcję, a w okresie szybkiego rozwoju stały się jeszcze bardziej dla niej podatnym gruntem. Niewątpliwie wzrost poziomu zamożności i zasobów narodowej gospodarki generuje dodatkowe pokusy ze strony jednostek i ośrodków powiązanych $\mathrm{z}$ władzą, w szczególności w instytucjonalnym środowisku, w którym państwo w dużym stopniu kontroluje gospodarkę i sektorowe kierunki rozwoju. Niemniej jednak kwestia wydaje się bardziej skomplikowana. Niektórzy twierdzą nawet, iż korupcja nie musi mieć negatywnych skutków dla rozwoju (Bramall, 
2009). Ten, wydawałoby się, paradoks ma miejsce w dwóch przypadkach: kiedy jej rozmiary są na tyle niewielkie, że nie zakłócają obranej ścieżki rozwojowej, bądź - co zdarza się niesłychanie rzadko - to korupcja jest odpowiedzialna za transfer zasobów do bardziej produktywnych sektorów gospodarki narodowej. Część ekspertów uważa, iż drugi przypadek miał miejsce w Korei Południowej, w okresie rządów Park Chung Hee (1963-1979) (zob. Bramall, 2009).

\section{ZAKOŃCZENIE}

Sukcesy rozwojowe wschodnioazjatyckich gospodarek, tj. Japonii, Korei Południowej i Tajwanu, w drugiej połowie XX w., są wynikiem wielu uwarunkowań politycznych i gospodarczych, zarówno regionalnych, jak i wewnętrznych. We wszystkich przypadkach kluczowe znaczenie miała koncepcja państwa rozwojowego, która określiła systemowe i instytucjonalne ramy działania, pozycję i rolę państwa, zakres i treść polityki rozwojowej, a także zdefiniowała relację poszczególnych uczestników procesu rozwojowego.

Według koncepcji państwa rozwojowego państwo musi pozostać w centrum procesów transformacyjnych i rozwojowych, a także utrzymać dominującą pozycję wobec społeczeństwa i sektora biznesowego. Poprzez doraźne działania osłabia społeczeństwo, a jednocześnie wzmacnia niektórych jego przedstawicieli, budując tym samym poparcie dla polityki rozwojowej. Przykładowo kreuje miejsca pracy poprzez politykę substytucji importu i ekspansji eksportu, zjednuje sobie biedotę i ubogie chłopstwo poprzez rozdawnictwo ziemi, osłabia konserwatywnie nastawionych obszarników ziemskich, odbierając im ich główny zasób, czyli ziemię. Z sektorem biznesowym zawiera sojusz i przymusza go do realizowania projektów w preferowanych przez siebie sektorach narodowej gospodarki, wyznaczonych w strategii uprzemysławiania. Niemniej jednak negocjuje i renegocjuje cele i instrumenty polityki rozwojowej, aby zwiększyć swoją legitymizację.

W dobie rosnących nierówności rozwojowych pomiędzy państwami, utrzymującym się zacofaniem wielu regionów świata i ostateczną dyskredytacją neoliberalnego modelu gospodarczego jako efektywnego środka walki z ubóstwem, koncepcja państwa rozwojowego powraca jako atrakcyjny model systemowo-instytucjonalny dla tych krajów rozwijających się, które chcą przyspieszyć swoją dynamikę rozwojową, a w obecnych warunkach globalizacji i rosnących współzależności ekonomicznych nie są w stanie dokonać skoku cywilizacyjnego. 
Państwo rozwojowe traktowane jest coraz częściej jako interesująca opcja dla niektórych państw afrykańskich, byłych republik radzieckich w Azji Centralnej, czy dla części państw Wspólnoty Gospodarczej Stowarzyszenia Narodów Azji Południowo-Wschodniej. Wiele rozwiązań w zakresie instytucji i polityki rozwojowej, wzorowanych na tej koncepcji, zastosowano w Chinach, które coraz częściej wymieniane są jako sukces transformacji, przy wszystkich swoich mankamentach rozwojowych. Istnieje zatem prawdopodobieństwo, iż koncepcja państwa rozwojowego odżyje jako ważna alternatywa. Wraz z nią powróci kwestia specyficznego kontraktu społecznego.

BibLIOGRAFIA:

Amsden, A.H. (1989). Asia's Next Giant: South Korea and Late Industrialisation. Oksford: Oxford University Press.

Bramall, Ch. (2009). Chinese Economic Development. Abingdon: Routledge.

Cumings, B. (1984). The Origins and Development of the Northeast Asian Political Economy. Industrial Sectors, Product Cycles and Political Consequences. International Organization, 38(1), 1-40.

Doner, R.F., Ritchie, B.K., Slater, D. (2005). Systemic Vulnerability and the Origins of Developmental States: Northeast and Southeast Asia in Comparative Perspective. International Organization, 59 (Spring), 327-361.

Evans, P. (1995). Embedded Autonomy: States and Industrial Transformation. Princeton, NJ: Princeton University Press.

Gallagher, M.E. (2005). Contagious Capitalism: Globalisation and the Politics of Labor in China, Princeton. NJ: Princeton University Press.

Guo, Y., Hu, A. (2004). The Administrative Monopoly in China's Economic Transition. Communist and Post-Communist Studies, 37, 265-280.

Haggard, S. (1990). Pathways from the Periphery, Ithaca, NY: Cornell University Press.

Hall, P.A., Soskice, D. (red.). (2001). Varieties of Capitalism. The Institutional Foundations of Comparative Advantage. Oksford: Oxford University Press.

Jeon, J.-G. (1995). Exploring the Three Varieties of East Asia's State-Guided Development Model: Korea, Singapore, and Taiwan. Studies in Comparative International Development, 30(3), 70-88.

Johnson, Ch.A. (1982). MITI and the Japanese Miracle: The Growth of Industrial Policy, 1925-1975. Stanford, CA: Stanford University Press.

Kong, T.Y. (2000). The Politics of Economic Reform in South Korea: A Fragile Miracle. Londyn i Nowy Jork: Routledge.

Kwong, J. (1997). The Political Economy of Corruption in China. Armonk: Sharpe.

Leftwich, A. (2000). States of Development: On the Primacy of Politics in Development. Cambridge i Oksford: Polity Press.

Maddison, M. (2007). Contours of the World Economy 1-2030 AD: Essays in Macro-Economic History. Oksford: Oxford University Press. 
Nozick, R. (1974). Anarchy, State, and Utopia. Oksford i Cambridge, MA: Blackwell.

Pareto, V. (1966). Sociological Writings. Londyn: Pall Mall Press.

Robinson, M., White, G. (red.). (1998). The Democratic Developmental State: Politics and Institutional Design. Oksford: Oxford University Press.

Stubbs, R. (2009). What Ever Happened to the East Asian Developmental State? The Unfolding Debate. The Pacific Review, 22(1), 1-22.

Wade, R. (1990). Governing the Market: Economic Theory and the Role of Government in East Asian Industrialisation. Princeton: Princeton University Press.

Woo-Cumings, M. (red.). (1999). The Developmental State. Ithaca: Cornell University Press.

Waldner, D. (1999). State Building and Late Development. Ithaca: Cornell University Press.

White, G. (red.). (1988). Developmental States in East Asia. Nowy Jork: Macmillan Press.

White, G., Wade, R. (1988). Developmental States and Markets in East Asia: An Introduction. W: White, G. (red.). Developmental States in East Asia. Nowy Jork: Macmillan Press. 